\title{
IMPACT ON COMPETITIVENESS OF VIETNAMESE COMMERCIAL BANKS: RESEARCH IN HO CHI MINH CITY
}

\author{
Ai Huu Tran \\ Tuan Duc Tran \\ Van Hien University, Ho Chi Minh City, Vietnam \\ Thanh Vinh Bui \\ Viettin Bank, Tay Tien Giang Branch, Ho Chi Minh City, Vietnam
}

This study has been designed to identify the factors affecting the competitive competence of commercial banks and to rank the priority among these factors as applied to bank leaders' planning and development strategies. According to the evaluation of managers, the impact of the factors affecting the competitive competence of commercial banks is gradually decreasing in the following order: Financial capacity, Quality of banking and financial services, Management capacity of executive management, Human resources, Technology capacity.

Keywords: competitiveness, commercial banks, strategy
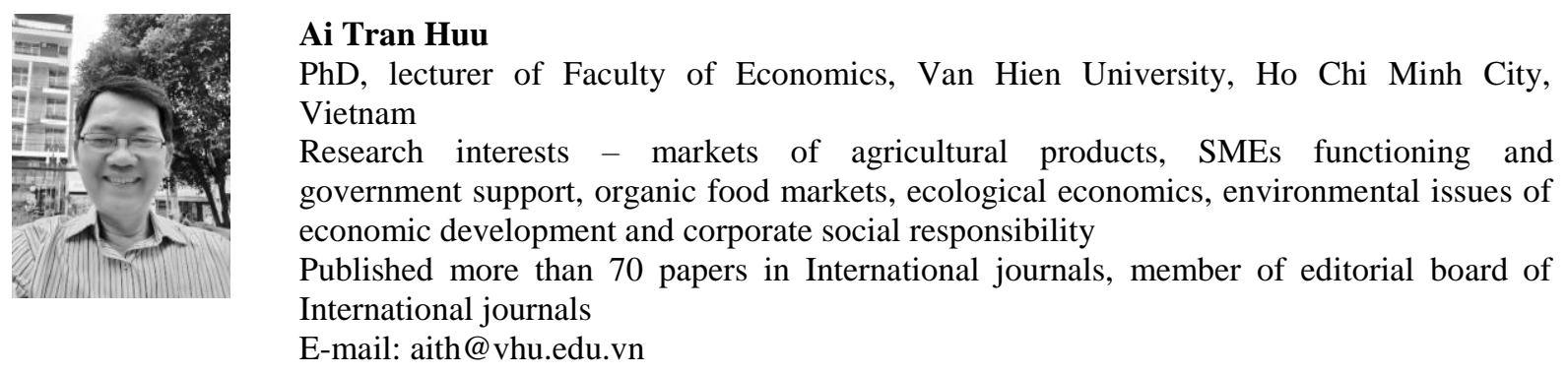
economic development and corporate social responsibility

Published more than 70 papers in International journals, member of editorial board of International journals

E-mail: aith@vhu.edu.vn

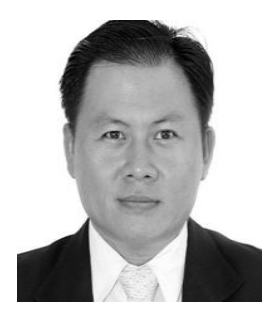

\section{Tuan Tran Duc}

Doctor of Business Administration, Specialist in the field of training and human development, Ho Chi Minh City, Vietnam

One of the first 6 people to receive a PEP (Personal Efficiency Program) Facilitator-United States in Vietnam, Doctor of Business Administration and Information System Université Libre de Bruxelles (ULB-Belgium), Doctor of Business Administration (BSU-Hongkong), Bachelor of Foreign Languages and completed the Professional Speakers course in Singapore.

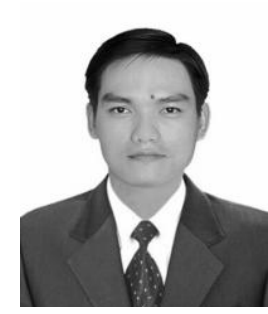

\section{Bui Vinh Thanh}

Master degree

Director Viettin Bank, Tay Tien Giang Branch, Ho Chi Minh City, Vietnam

Research interests: SMEs functioning and government support, consumer behavior, innovative products markets and finances.

Published more than 10 papers in International journals. 


\section{IMPACT ON COMPETITIVENESS OF VIETNAMESE}

\section{Introduction}

Vietnam became the official member of the World Trade Organization (WTO), and this came along with the opportunities and challenges for the development of each commercial bank in Vietnam. Thus, competitive pressure on Vietnamese commercial banks is increasing these days. In 3 years from 2016 to 2018, 4 more foreign banks were licensed to operate in Vietnam, thus increasing their number to 9 banks with $100 \%$ foreign capital.

Most of these 9 banks with 100\% foreign capital in Vietnam back in 2018 demonstrated superior business results as compared to local banks of the same size in terms of capital and total assets.

This shows that some of the benefits local banks may have in their own country, foreign banks are still enjoying certain advantages and overall higher profitability. Expanding the network, especially in large cities and provinces with large industrial zones, is a relatively new strategy among foreign banks in Vietnam and it is showing that they are willing to compete with domestic banks for the local customer base.

As of December 31, 2018, the total of 49 foreign bank branches were operating in Vietnam. Sumitomo Mitsui Bank (SMBC) is the bank with the largest chartered capital (VND 11,200 bln), it has two branches. After the withdrawal of Techcombank from HSBC Vietnam Ltd., Australia's Commonwealth Bank sold its branch in Ho Chi Minh City to VIB, BNP Paribas sold out $18.7 \%$ of equity in OCB after a decade of cooperation, and Standard Chartered also sold $8.75 \%$ of ACB shares after 12 years of working at this market. While foreign banks have withdrawn their capital from domestic banks, the number of $100 \%$ foreign-owned banks has increased recently.

The increasing level of competition has forced Vietnamese banks to improve their productivity and operational efficiency. Many commercial banks have invested heavily in advanced digital technologies and development of their human resources so that to establish the infrastructure necessary for the development of products and services meeting the increasing demands of customers and also to proactively face the challenges from integration observed in Vietnamese banking sector.

Against the background of mostly positive effects, some of the banks have been actually competing rather excessively and "behaved unhealthy" in raising capital and credit, even defying the law, ignoring risk warnings and so on. This segment has brought many consequences to the stability of the banking system. Firstly, commercial banks are now racing for interest rates in the context of fierce competition, many banks have mobilized capital going behind the SBV regulations.

This high pressure has put many banks at risk of credit squeeze back in 2019. Finding competitive strategies to maintain profits continues to be a real headache for banks, especially when the marginal interest rate (NIM) ratio is likely to fall, as deposit rates have risen sharply recently, while lending rates are unlikely to increase accordingly.

From 2019 onwards, banks will face greater pressure on credit contraction. Along with that, there is ongoing competition on cost cutting, improving profitability and financial resilience. In this context, commercial banks have to dive deep into digitization to minimize the growing costs of administration, management, human resources, investment in facilities, etc. 


\section{Theoretical basis}

Competition is understood as trying to win more among the organizations that are working for the same benefits. Competitive capability in this context can be considered as a dependent or independent variable, depending on a particular perspective and the selected approach to the problem. Competitive capability is a multi-dimensional concept, it can be considered at 4 different levels: international level (Smith, 1995; Momaya, 2000), national level, industry level (Momaya, 1998) and company level (Man TWY et al., 1998). Competitive capability refers to "a combination of assets and processes, in which assets are inherited (natural resources, available resources) or created (infrastructure) and processes, asset conversion process to gain economic benefits from the sale of service products "(DC, 2001). Competitive capability is a common concept to describe the power of an economic entity with respect to its competitors in the global market economy (Murths et al., 1998).

According to Porter (1980): "To be able to compete successfully, businesses must have a competitive advantage in the form of either lower production costs, or the ability to differentiate products to achieve higher than average prices. In order to maintain a competitive advantage, businesses need to increasingly gain more sophisticated competitive advantages, which can provide higher quality goods or services or produce more efficient production". According to Cronin et al. (1992), competitiveness should be linked to the mission of an enterprise with three elements: core values, main goals and goals to help businesses perform their functions.

Therefore, this study applies the Thompson - Strickland (2001) model to measure weaknesses affecting the competitiveness of banks in HCMC. More specifically, 7 components are investigated here: Financial capacity, Technology capacity, Executive management capacity, Human resources, Research capacity, Business culture, Operational capacity.

\section{1) Financial capacity}

Good financial capacity will help that commercial bank easily gain customers' confidence in mobilizing capital as well as in lending, increasing the size of total assets, increasing the maximum loan volume for a customer. Financial capacity of a bank is the capacity to ensure financial resources for its operations to achieve the goals set out by the bank (Pham Thu Huong, 2017). Financial capacity is a measure of a bank's strength at a given time, usually assessed through: Scale of capital and total assets, the ability to mobilize capital, quality of available assets, profitability, liquidity, and the level of risks (Tran Huu Ai, 2017).

When emphasizing the importance of human and material resources, we cannot overlook another aspect, perhaps one of the most important aspects in ensuring all activities and competitiveness of enterprises, namely, access to finance and their effective use (Becchetti \& Trovatto, 2002; Bougheas, 2004; Pissarides, 1999). Therefore, hypothesis H1 is proposed as follows:

H1: Financial capacity has a positive influence on the competitiveness of commercial banks in Ho Chi Minh City. 


\section{IMPACT ON COMPETITIVENESS OF VIETNAMESE}

\section{2) Technology capacity}

Technological competencies go hand in hand with network and diversification, leading to the development of new, breakthrough products and services. Practices in the field have proved that development of risk management processes following the international standards can only be performed best on the basis of most advanced technologies which can be divided into the following groups of technologies: Core banking systems, technologies of the application level, the ability to upgrade and renew technologies, facilities and techniques. Studies by Hudson's (2001); Quian, Li (2003); Chowdhury (2013); Tho \& Trang, (2009) show that the following characteristics of technologies are impacting the competitive capabilities of banks: Gradual technological innovation; Appropriate technology; Capacity to apply and access new technologies; Human resources engaged in research and application of new technologies in the bank. According to (Nguyen et al., 2007a), despite facing the urgent need for technological innovations and enhancing competitive advantage, many private banks in Vietnam are not able to apply new technologies due to insufficient labor force, insufficient capital and poor skills among management. Therefore, hypothesis $\mathrm{H} 2$ is proposed as follows:

H2: Technology capacity has a positive influence on the competitiveness of commercial banks in Ho Chi Minh City.

\section{3) Executive management capacity}

According to Boyatzis (1982), management capacity of a company manager or of a group of employees is always contributing to successful completion of tasks. Therefore, management competence is understood here as a set of observable characteristics such as knowledge, skills, or behavioral patterns that contribute to successful completion of management tasks (Markman, 2007; Mitchelmore and Rowley 2010; Talik et al., 2012). Various studies suggest that management capacity is essential for success and growth of companies (Rowley, 2010). General management capacity affects banks indirectly through more specific management capacities. Therefore, business management and management capacity should be considered as an important predictor of business success (Markman, 2007; Mitchelmore and Rowley, 2010). Therefore, hypothesis H3 is proposed as follows:

H3: Executive management has a positive influence on the competitiveness of commercial banks in Ho Chi Minh City.

\section{4) Human resources}

Human resources are very important because they ensure creativity in organizations. Human resources are the most dynamic factor, determining the efficiency of production and business overall. Labor force uses facilities and equipment to produce goods and services, participate in technical improvement and rationalize the production process (Tran Huu Ai, 2018). King-Kauanui, Sue and Ashley-Cotleur (2006) have shown that Vietnam's human resource management activities are more labor-intensive than elsewhere.

According to Tahir \& Bakar (2007), service capacity is reflected in the desire and willingness of staff to provide timely service to customers in order to bring satisfaction to them. It is reflected in the attitude and skills of employees in the service process and personnel policy. Therefore, hypothesis $\mathrm{H} 4$ is proposed as follows:

H4: Human resources positively influence the competitiveness of commercial banks in Ho Chi Minh City. 


\section{5) Quality of financial and banking services}

The quality of financial and banking services is expressed through such aspects as utility and safety of the related products and services; accuracy of products and services; time of supplying products and services; degree of simplicity or complexity of a product/service.

The market share of a commercial bank reflects the size of its activity at a market. The market share of each commercial bank is reflected through the number of customers, the number of outstanding loans and so on. The reputation of each commercial bank is only created after a long time, through the form of ownership, staff, the application of high-tech products, and also through full satisfaction of customer needs which, in its turn, is increasing high demand among customers. Therefore, the hypothesis $\mathrm{H} 5$ is proposed as follows:

H5: The quality of banking and financial services positively affects the competitiveness of commercial banks in Ho Chi Minh City.

\section{The relationship between the factors and the competitiveness of commercial banks in HCM}

For a range of obvious reasons, no commercial bank is able to fully satisfy all customer requirements. The basic problem here is that commercial banks must be aware of this and try to promote their strengths while trying to meet the requirements of customers. Strengths and weaknesses of a commercial bank are manifested through its key operational areas, such as marketing, finance, manufacturing, human resources, technologies, management and information systems. However, to assess the competitiveness of a commercial bank, it is necessary to identify the factors that reflect the competitiveness from different angles of activities, thus, conducting a qualitative assessment and quantification would be often needed. Commercial banks doing business in different industries and sectors have different competitiveness assessment factors. However, it is still possible to synthesize the competitiveness factors of a commercial bank, for example: product and service prices; product quality and package; distribution channels; information and trade promotion; research and development capacity; brand and reputation; labor qualifications; market share in its dynamics; financial position; organizational capacity, relationship marketing capacity, adaptive capacity and commercial bank management.

Table 1 - Scales of variables in the proposed model

(Source: Summary of the studies above)

\begin{tabular}{|l|l|}
\hline \multicolumn{1}{|c|}{ Scale } & \multicolumn{1}{c|}{ Original scale } \\
\hline Financial capacity & Becchetti \& Trovatto, 2002; Bougheas, 2004 \\
\hline Technological capacity & Quian, Li, 2003; Chowdhury, 2013 \\
\hline Executive management capacity & Markman, 2007; Talik, 2012 \\
\hline Human resources & King-Kauanui, Su và Ashley-Cotleur, 2006 \\
\hline $\begin{array}{l}\text { Quality of financial and banking } \\
\text { services }\end{array}$ & Zouet al., 1998; Jorge Carneiro, 2011 \\
\hline
\end{tabular}




\section{IMPACT ON COMPETITIVENESS OF VIETNAMESE}

\section{Research methods}

The main objective of this study is to measure the level of competition among the commercial banks in Vietnam. The independent variables are financial capacity, technological capacity, executive management capacity, human resources, service quality, while competitiveness of commercial banks is a dependent variable. The research uses qualitative methods to build a scale of concepts for the research model (Figure 1). The observed variables were measured on the 5-point Likert scale, with 1 being strongly disagree and 5 being strongly agree.

The survey was conducted from June 2019 to September 2019, the respondents of the questionnaire were all on the management positions in commercial banks. These are subjects who are knowledgeable about the business activities of commercial banks and who are responsible for the business operation results of commercial banks. The total number of the surveyed units is 58 commercial banks, the total sample size is 320 questionnaires selected by means of random method, the collected valid number used as research data is 292 survey questionnaires. The data was then analyzed in SPSS 23.0, using namely the scale reliability test (Cronbach alpha), discovery analysis (EFA), confirmatory analysis (CFA) and regression analysis.

Confirmatory factor analysis is one of the statistical techniques of linear structure model (SEM). CFA lets us test how well our measured variables represent the constructs. CFA is the next step of EFA because CFA is only used appropriately when the researcher has some knowledge of the underlying structure, in which the relationship or hypothesis (derived from a theory or an experiment) between the observed variables and the baseline factor is assumed by the researcher before conducting the statistical testing. In our particular case, CFA method is used to confirm the univariate, multivariate, convergence and discrimination values of the evaluation scale of the competitive capability evaluation of commercial banks in Ho Chi Minh City.

\section{Data analysis and results}

The suggested research models extracted from the related foreign models to measure the factors affecting competitiveness when applied in specific cases at Vietnamese commercial banks need to be re-tested to see if they reach the sufficient level of trust or not.

\section{Survey sample description}

The data set was collected from 58 commercial banks in Ho Chi Minh City. More details on the studied banks are presented in Tab. 2 . 
Table 2 - Characteristics of the surveyed commercial banks in HCMC

(Source: Data collected by the authors)

\begin{tabular}{|c|c|c|}
\hline Ownership & Amount & \% \\
\hline Joint-stock commercial banks & 22 & 37.93 \\
\hline Private commercial banks & 32 & 55.17 \\
\hline 100\% foreign owned & 4 & 6.90 \\
\hline Total & $\mathbf{5 8}$ & $\mathbf{1 0 0 . 0 0}$ \\
\hline Size & Quantity & \% \\
\hline Under 250 & 4 & 6.90 \\
\hline$>250-<400$ & 27 & 46.55 \\
\hline$>400<600$ & 17 & 29.31 \\
\hline Over 600 & 10 & 17.24 \\
\hline Total & $\mathbf{5 8}$ & $\mathbf{1 0 0 . 0 0}$ \\
\hline
\end{tabular}

\section{Cronbach Apha's reliability coefficient test results for the scale}

Tab. 3 shows that Cronbach's Alpha coefficients for all the scales are greater than 0.7, the correlation total coefficients are greater than 0.4. Therefore, all the scales are further used in the next steps of our analysis - EFA, CFA and SEM (Nunnally \& Burnstein, 1994).

Table 3 - Cronbach's Alpha test results for scales (Source: calculated by the authors)

\begin{tabular}{|c|l|c|c|c|}
\hline $\mathbf{N}$ & \multicolumn{1}{|c|}{ Scale } & Variable & $\begin{array}{c}\text { Cronbach } \\
\text { Alpha }\end{array}$ & $\begin{array}{c}\text { Corrected Item- } \\
\text { Total } \\
\text { Correlation }\end{array}$ \\
\hline 1 & Financial capacity & 6 & 0.933 & 0.698 \\
\hline 2 & Technological capacity & 5 & 0.921 & 0.704 \\
\hline 3 & Executive management capacity & 5 & 0.886 & 0.616 \\
\hline 4 & Human resources & 4 & 0.837 & 0.590 \\
\hline 5 & Quality of financial and banking services & 4 & 0.787 & 0.490 \\
\hline 6 & Competitiveness of a commercial bank & 4 & 0.725 & 0.415 \\
\hline
\end{tabular}

\section{EFA discovery factor analysis}

The scale of the research concepts was assessed and pre-screened by the EFA discovery factor analysis method and Cronbach Alpha coefficient as applied to each component. Selection criteria are variables that must have variable coefficients (item total correlation) being > 0.30; Cronbach's coefficient Alpha being >0.60; factor loading being $>0.40$. The scale is satisfactory when the total variance is $\geq 50 \%$ (Hair et al., 1998). The 


\section{IMPACT ON COMPETITIVENESS OF VIETNAMESE}

factor extraction method used was Principal Axis Factoring (PAF) with non-square rotation of Promax.

The results of the exploratory factor analysis (EFA) show that 24 observed variables in the 5 components of the competitive competence scale of commercial banks also kept the same 5 factors with 24 observed variables. KMO coefficient $=0.790$, therefore, EFA is consistent with the data and Chi-quare statistics of Bertlett's test is reaching 6874.384 with the significance level of 0.000 . This means that the observed variables are correlated with each other in terms of the overall scope. The variance extracted by 72.071 indicates that the five factors were explained by $72.071 \%$ of the data variation, while the eigenvalue coefficients are equal to 1.322. Therefore, the scale drawn is acceptable.

Table 5 shows that the dependent variable has a rather strong linear correlation at the significance level $\alpha<0.05$ with 5 independent variables - Financial capacity, Technological capacity, Executive management capacity, Human resources, Quality of financial banking services. Because all the absolute correlation coefficients between the variables ranged from 0.153 to 0.607 , this means that the condition $-1 \leq r \leq+1$ is satisfied. Therefore, all the variables meet the requirements for multiple linear regression analysis. This proves that the discriminatory value has been achieved, or in other words, the scales in this study measure different research concepts. The correlation matrix also shows that financial variables have the strongest impact on the dependent variable of banks' competitive capability. In contrast, human resource variables have the least impact on the dependent variable of competitive capability.

\section{Matrix correlation coefficient analysis}

The first step in analyzing linear regression is to examine the correlation, linear between all the variables, which means that we must consider the general relationship between each independent variable with the dependent variable and between the independent variables, as described by (Hoang Trong and Chu Nguyen Mong Ngoc, 2008).

\section{Confirmatory factor analysis}

The CFA results of the first commercial bank scale of competitive competence demonstrate that variables FC1, FC2 belong to the Financial capacity component, and EMC1, EMC3 belong to the Executive management capacity component because the weight of this variable is smaller than the allowed standard $(>=0.5)$, the scale reaches the convergent value (Gerbing \& Anderson, 1988). Thus, these variables will be disqualified before the second CFA is conducted, in which the statistically significant values of $\mathrm{P}$ are all equal to 0,000 (the lowest is the variable NV4 with the weight of 0.528 ). 
Table 4 - EFA results on the competitive competence scale of commercial banks (Source: calculated by the authors)

\section{Pattern Matrix}

\begin{tabular}{|c|c|c|c|c|c|}
\hline & \multicolumn{5}{|c|}{ Component } \\
\hline & $\begin{array}{l}\text { Financial } \\
\text { capacity } \\
\text { (FC) }\end{array}$ & $\begin{array}{l}\text { Technological } \\
\text { capacity } \\
\text { (TC) }\end{array}$ & $\begin{array}{c}\text { Executive } \\
\text { management } \\
\text { capacity (EMC) }\end{array}$ & $\begin{array}{c}\text { Human } \\
\text { resource } \\
\mathrm{s} \\
(\mathrm{HS})\end{array}$ & $\begin{array}{c}\text { Quality of } \\
\text { financial and } \\
\text { banking services } \\
\text { (QFB) }\end{array}$ \\
\hline Financial capacity 1 & 0.962 & & & & \\
\hline Financial capacity 2 & 0.957 & & & & \\
\hline Financial capacity 5 & 0.955 & & & & \\
\hline Financial capacity 6 & 0.770 & & & & \\
\hline Financial capacity 3 & 0.759 & & & & \\
\hline Financial capacity 4 & 0.707 & & & & \\
\hline Technological capacity5 & & 0.918 & & & \\
\hline Technological capacity4 & & 0.864 & & & \\
\hline Technological capacity1 & & 0.847 & & & \\
\hline Technological capacity2 & & 0.753 & & & \\
\hline Technological capacity3 & & 0.751 & & & \\
\hline Executive management 2 & & & 0.875 & & \\
\hline Executive management 1 & & & 0.873 & & \\
\hline Executive management 3 & & & 0.784 & & \\
\hline Executive management5 & & & 0.777 & & \\
\hline Executive management 4 & & & 0.732 & & \\
\hline Human resources4 & & & & 0.814 & \\
\hline Human resources1 & & & & 0.754 & \\
\hline Human resources3 & & & & 0.751 & \\
\hline Human resources2 & & & & 0.699 & \\
\hline QFB1 & & & & & 0.830 \\
\hline QFB2 & & & & & 0.802 \\
\hline QFB3 & & & & & 0.787 \\
\hline QFB4 & & & & & 0.695 \\
\hline$\%$ of variance & 32.775 & 48.135 & 57.903 & 66.565 & 72.071 \\
\hline Eigenvalues & 7.866 & 3.686 & 2.344 & 2.079 & 1.322 \\
\hline Cronbach's Alpha & 0.933 & 0.921 & 0.886 & 0.837 & 0.787 \\
\hline
\end{tabular}

Table 5 - Correlation coefficients between the components (Source: calculated by the authors)

\begin{tabular}{|l|l|c|c|c|c|c|c|}
\hline TC & FC & TC & EMC & HS & QFB & CCB \\
\hline FC & Pearson Correlation & 1 & & & & & \\
\hline TC & Pearson Correlation & $0.300^{* *}$ & 1 & & & & \\
\hline EMC & Pearson Correlation & $0.457^{* *}$ & $0.390^{* *}$ & 1 & & & \\
\hline HS & Pearson Correlation & $0.180^{* *}$ & $0.602^{* *}$ & $0.260^{* * *}$ & 1 & & \\
\hline QFB & Pearson Correlation & $0.162^{* *}$ & $0.162^{* *}$ & $0.207^{* *}$ & $0.153^{* *}$ & 1 & \\
\hline CCB & Pearson Correlation & $0.607^{* *}$ & $0.493^{* *}$ & $0.543^{* *}$ & $0.426^{* *}$ & $0.494^{* *}$ & 1 \\
\hline$* * 0$, Correlation is significant at he 0,01 level (2-tailed). \\
\hline
\end{tabular}

Thus, it can be concluded that the observed variables measuring the 5 components of the service quality scale achieve the convergent values. The second CFA shows that the model has 105 degrees of freedom, chi-square test value $=203.070$ with $p$-value $=0,000$, but 
chi-square / $\mathrm{df}=1.934$ meets the requirements $<2$ and the indicators show that the model is suitable for market data $(\mathrm{CFI}=0.951$, $\mathrm{TLI}=0.937$, GFI $=0.924$ and $\mathrm{RMSEA}=0.057)$. However, only two components achieved unidirectional (TB) and spatial (KG) results, the other had a correlation between the errors of the observed variables, so they did not achieve unidirectional result. The correlation coefficients between the components and the associated standard deviation (see Table 5) shows that these coefficients are less than 1 (which is statistically significant). Therefore, the components of financial capacity, Technological capacity, Executive management capacity, Human resources1, Quality of financial services banking are all established. The value and reliability of the scale will be assessed by the aggregate reliability coefficient and extracted variance (see Table 6). This result shows that the components of the competitive competence scale of commercial banks all meet the requirements of value and reliability.

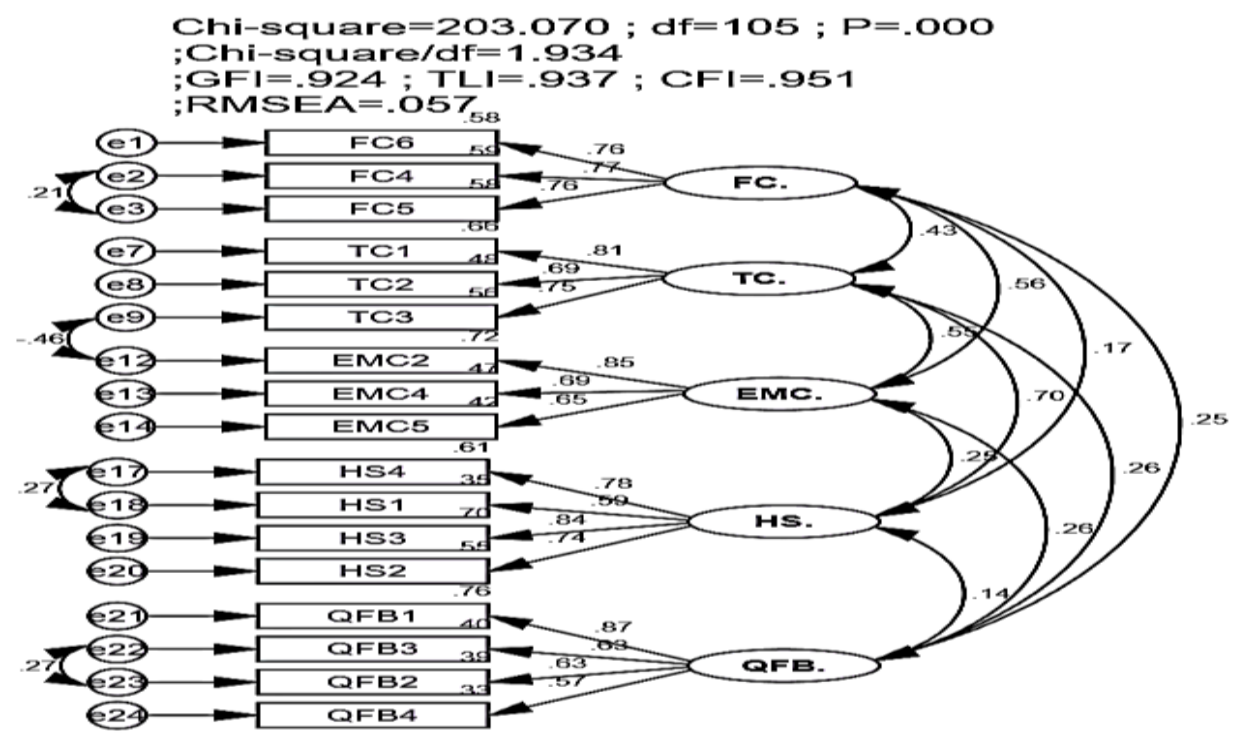

Figure 2 - CFA results of the commercial bank scale of competitive competence (standardized)

(Source: calculated and designed by the author)

Thus, after the CFA analysis, the service quality scale includes 5 components which are FC, TC, EMC, HS and QFB with 17 observed variables, of which, the FC composition has changed, measured by 4 variables ( $\mathrm{FC} 1$ and $\mathrm{FC} 2$ variables as compared to EFA results). The composition of the SFEs variable is measured by the three observed variances (types of EMC1 and EMC3 as compared to EFA results). The CFA results show that all the components of the scale have achieved the needed convergence value, discriminant value and satisfactory value and reliability. 
Table 6. The results of testing the discriminant value among the components of the competitive competence scale of commercial banks

(Source: calculated by the authors)

\begin{tabular}{|lll|cllc|}
\hline \multicolumn{3}{|c|}{ Relations } & Estimates & S.E. & C.R. & P \\
\hline CCB & $<-->$ & TC & 0.130 & 0.027 & 4.826 & $* * *$ \\
CCB & $<-->$ & EMC & 0.195 & 0.030 & 6.588 & $* * *$ \\
CCB & $<-->$ & HS & 0.063 & 0.028 & 2.272 & 0.023 \\
CCB & $<-->$ & QFB & 0.116 & 0.032 & 3.591 & $* * *$ \\
TC & $<-->$ & EMC & 0.132 & 0.023 & 5.808 & $* * *$ \\
TC & $<-->$ & HS & 0.216 & 0.028 & 7.643 & $* * *$ \\
TC & $<-->$ & QFB & 0.059 & 0.024 & 2.411 & 0.016 \\
EMC & $<-->$ & HS & 0.099 & 0.024 & 4.199 & $* * *$ \\
EMC & $<-->$ & QFB & 0.070 & 0.026 & 2.700 & 0.007 \\
HS & $<-->$ & QFB & 0.059 & 0.027 & 2.187 & 0.029 \\
\hline
\end{tabular}

Table 7 - Summary table of scale inspection results

(Source: calculated by the authors)

\begin{tabular}{|l|c|c|c|c|}
\hline \multicolumn{1}{|c|}{ Components } & $\begin{array}{c}\text { Number of } \\
\text { variables }\end{array}$ & $\begin{array}{c}\text { Cronbach } \\
\text { Alpha }\end{array}$ & \% of variance & $\begin{array}{c}\text { Evaluation } \\
\text { result }\end{array}$ \\
\hline Financial capacity & 4 & 0.888 & 29.752 & \\
\cline { 1 - 4 } Technological capacity & 3 & 0.830 & 44.545 & \\
\cline { 1 - 4 } Executive management capacity & 3 & 0.767 & 57.032 & \multirow{2}{*}{ Qualified } \\
\cline { 1 - 4 } Human resources & 4 & 0.837 & 64.746 & \\
\cline { 1 - 4 } $\begin{array}{l}\text { Quality of financial and banking } \\
\text { services }\end{array}$ & 4 & 0.787 & 71.038 & \\
\hline
\end{tabular}

Table 8 shows that the coefficient of determination $\mathrm{R}^{2}$ is 0.665 and the adjusted $\mathrm{R}^{2}$ is 0.664 , which means that the model has explained $64.7 \%$ of the variation of the competitive capacity (dependent variable) for the variables in the model, while the rest of $35.3 \%$ is explained by the variables outside the model. In addition, the statistical value $\mathrm{F}$ reaches the level of 107.850 calculated from the adjusted $\mathrm{R}^{2}$ value $=0.664$ at the significance level $\mathrm{Sig}=$ 0.000 ; then we also checked the correlation phenomenon by means of Durbin-Watson coefficients $(1<1.021<3)$. Thus, the multiple linear regression model is consistent with the research data. 
Table 8 - Adjustment coefficient $\mathrm{R}^{2}$ and coefficient $\mathrm{F}$

(Source: calculated by the authors)

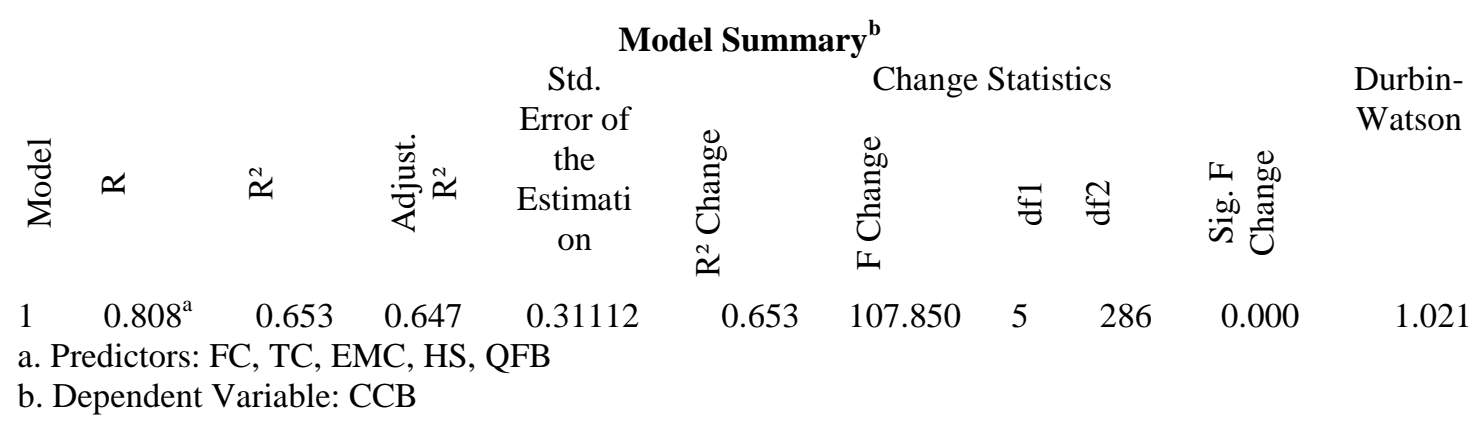

Tab. 9 presents the results of the multiple linear regression analysis of the relationship between the affecting factors. In our model, there is a correlation with the significance level smaller than 0.05 , positively correlated with the competitiveness of commercial banks. Tab. 9 also shows that the tolerance of the variables is at the acceptable level - from 0.460 to 0.809 , and the VIF of all 10 factors is less than 2 .

That is, there is no multicollinearity observed between the independent variables in question. The scatter plot between the residual and the predicted value of the regression model shows there is no relationship between the remainder and the predicted value, thus assuming the linearity of the model being accepted.

Table 9 - Results of the multiple regression analysis

(Source: calculated by the author)

\begin{tabular}{|c|c|c|c|c|c|c|c|c|}
\hline \multicolumn{9}{|c|}{ Coefficients $^{\mathrm{a}}$} \\
\hline \multirow{2}{*}{\multicolumn{2}{|c|}{ Model }} & \multicolumn{2}{|c|}{$\begin{array}{l}\text { Unstandardized } \\
\text { Coefficients }\end{array}$} & \multirow{2}{*}{$\begin{array}{c}\begin{array}{c}\text { Standardiz } \\
\text { ed } \\
\text { Coefficient } \\
\text { s }\end{array} \\
\text { Beta }\end{array}$} & \multirow[t]{2}{*}{$\mathrm{t}$} & \multirow[t]{2}{*}{ Sig. } & \multicolumn{2}{|c|}{ Collinearity Statistics } \\
\hline & & $\mathrm{B}$ & Std. Error & & & & Tolerance & VIF \\
\hline \multirow{6}{*}{1} & (Constant) & -.083 & .176 & & -.471 & .638 & & \\
\hline & $\mathrm{TC}$ & .282 & .029 & .390 & 9.822 & .000 & .770 & 1.299 \\
\hline & $\mathrm{FC}$ & .124 & .039 & .145 & 3.131 & .002 & .568 & 1.759 \\
\hline & EMC & .190 & .040 & .194 & 4.705 & .000 & .709 & 1.410 \\
\hline & HS & .149 & .039 & .167 & 3.811 & .000 & .634 & 1.578 \\
\hline & QFB & .308 & .032 & .342 & 9.528 & .000 & .941 & 1.062 \\
\hline
\end{tabular}

Therefore, the regression equation for the variables with non-standardized coefficients has the following form:

$$
\mathrm{CCB}=0.083+0.282 * \mathrm{FC}+0.124 * \mathrm{TC}+0.190 * \mathrm{EMC}+0.149 \mathrm{HS}+0.308 * \mathrm{QFB}+\varepsilon_{\mathrm{i}}
$$




\section{Conclusion}

\section{Discussion of the obtained results}

From a management perspective, with a more comprehensive approach to competitive capability, this study proposes and tests the theoretical model of the relationship between capacity factors and the impact of these factors on the competitive competence of commercial banks. The results of the competitive capability scale of commercial banks in Ho Chi Minh City according to the evaluation of commercial bank managers include 5 components: (1) Financial capacity, (2) Technology capacity, (3) Executive management capacity, (4) Human resources and (5) Quality of financial services with 17 factors. The components of the scale contribute information which is the basis for further evaluation and consultations of commercial bank managers and also the basis for the solutions improving the competitive capability of commercial banks in their business activities.

\section{Solutions}

According to this study, each commercial bank in our sample needs to improve the following factors: (1) Financial capacity, (2) Technological capacity, (3) Executive management capacity, (3) (4) Human resources, and (5) Quality of financial and banking services. Together, these improvements would contribute to the improved competitive capability of commercial banks.

- Financial capacity: safe financial management creates trust of customers. Trust among customers eventually leads to higher awareness, and awareness, in its turn, has a good impact on competitive advantages of banks. In banking, just like in any other industry, strong competitive advantage attracts new customers and/or attracts former customers of one's competitors.Therefore, in the banking sector, it is highly necessary to improve safety and reputation in service provision. In order to achieve the highest level of customer satisfaction and contribute to increased competitive advantage, banks need to provide reliable services, or in other words, they need to improve safety and reputation in their transactions.

- Technological capacity: Commercial banks need to invest in upgrading their facilities, equipment and in the most advanced technology. At this, they need to make sure though that the improved products/services suit consumer needs and the market overall. There can't be an ideal product/service that would satisfy all needs of all customers, so understanding customers and understanding changing differences in customer needs for products/services is the basic technical requirements for commercial banks when they are doing their research. Research, design and creation of banking products should be accompanied by the appropriate technologies. This can also be a good starting point for commercial banks in their process of customer segmentation, positioning, deciding on product pricing, integrated communication through technology and tech-supported customer care.

- Executive management capacity: This aspect means the use of human resources to influence commercial banks' business activities. Only human resources are able to convert other inputs (material, financial, information resources) into products and services that will then meet the relevant needs of the market. Stemming from management characteristics as described in our research, we can clearly see the very important role of management system, which sometimes determines the very survival of commercial banks. If commercial bank manages to arrange an appropriate management system, its services will be highly effective, 


\section{IMPACT ON COMPETITIVENESS OF VIETNAMESE}

saving time and work resources on both sides. And this would be always appreciated by bank customers. In this context, well-tuned management can be compared to a lightweight machine which saves costs and makes fast and right decisions at the same time.

- Human resources: This aspect of our study covers such things as job orientation and staff development programs. Both of them are enabling new and current employees learn more about commercial banks and become better aware of their position and role in organization. Vietnamese commercial banks, especially domestic commercial banks without foreign shares in ownership, should invest in researching and implementing more advanced training models which are already applied by major financial institutions in the world. Having a training center or a training school with a professional training model of their own would perfectly meet the requirements to training and development of human resources in banks. Indirectly, staff development is also serving the society overall as it contributes to personal development of employees as members of the local community.

Content of such training programs should be in accordance with today's competency standards and task functions as per each job title in a bank. In addition to providing professional knowledge directly related to banking, in the course of staff trainings banks also need to focus on improvement of other imporant working skills among employees, especially those related to customer service, namely: interpersonal skills, sales consulting skills, negotiation skills, customer care skills and so on.

- Quality of financial and banking services: The ongoing process of international economic integration has led to an increasingly fierce competition among commercial banks at many national and regional financial markets. Therefore, provision of high-quality products and services is one of the factors that play an important role in contributing to improved competitive advantages, increasing profits, bringing a stable source of income, preventing potential risks and strengthening bank growth overall.

- Enhanced marketing and customer care: In business, marketing and customer care belong to the factors with the most important role in communication with current and potential customers. Both of them rest on the ability to identify key benefits of products / services as well as on brand awareness among customers. Efficient cooperation of marketing and customer care departments in a bank would allow maintaining long-term commitment of customers to the bank.

In order for the above activities to achieve high efficiency, the bank needs to implement the following solutions:

- Identifying target customers. These can be VIP customers, large customers, traditional customers, common customers etc. For each group, the bank needs to have a separate strategy of promotional activities, communication and customer care.

- In part of promotion and communication activities, the bank should focus on selecting the most appropriate communication channels which have proven effective means of promotion.

\section{Limitations and suggestions}

This research study has been limited in both time and resources, therefore, it has not been able to cover all commercial banks in Vietnam in general. In the future, the authors wish to expand the scope of this research through assessment of other factors, also related to 
competitive competence of commercial banks in Vietnam. Our suggestions for future research in this direction would be as follows:

- Assessing the supply side of servicing in Vietnamese banking system, including analysis and evaluation of each specific service type in each service group. Separately can be considered fee-based services and mixed services of Vietnamese commercial banks;

- Expanding the research on the opinions of bank managers, namely those responsible for planning their business strategies or policy development. This would allow having a more general view on the competitive competence of commercial banks in Vietnam today.

- Finally, in terms of survey sampling, further studies may expand or incorporate additional sampling methods such as stratified sampling, probabilistic sampling, norms ratio and so on.

\section{References:}

Angur, M. G., Nataraajan, R. \& Jahera, J. (1999). Service in the banking industry: an assessment in a developing economy. International Journal of Bank Marketing, 17,3: 116-123.

Akan, P. (1995). Dimensions of service quality: a study in Istanbul. Managing Service Quality, 5,6: $39-43$.

Aldlaigan, A. H. \& Buttle, A. (2002). SYSTRA-SQ: a new measure of bank service quality. International Journal of Service Industry Management, 13,4: 362-381.

Ai Huu Tran (2017). Environmental impacts on small and medium enterprise effectiveness (the case of the fisheries sector in Vietnam). The EUrASEANs: journal on global socioeconomic dynamics, 2 (4).

Ai Huu Tran (2017). Managerial efficiency and enterprise performance (the case of aquaculture industry in VIETNAM). The EUrASEANs: journal on global socioeconomic dynamics, \# 4 (5).

Ai Huu Tran (2018). Competitive assessment factors of seafood exporters in Vietnam. The EUrASEANs: journal on global socioeconomic dynamics, 4 (11).

Boyatzis, R.E. (1982). The competent manager: a model for effective performance. New York: John Wiley and Sons.

Cronin, J. J., \& Taylor, S. A. (1992). Measuring service quality: A re-examination and extension. Journal of Marketing, 56(1), 55-68.

Hair, J.F., Black, W.C., Babin, B.J., \& Anderson, R.E., (2010). Multivariate data analysis. Prentice Hall. Upper Saddle River, NJ.

Martínez-López, F., Gázquez-Abad, J. \& Sousa, C. (2013). Structural equation modelling in marketing and business research. European Journal of Marketing, 47,1/2: 115-152.

Momaya, (2004). Development of Competitive Strategy. Hindustan Publishing Co, New Delhi.

OECD (2002). Global competition report. Department of Foreign Affairs, Ho Chi Minh, Vietnam.

Pham Thu Huong (2017). Competitiveness of small and medium-sized enterprises, research in the Hanoi area. Doctoral thesis. Hanoi University of Mining and Geology.

Porter, M. E. (1980). Competitive Strategy: Techniques for Analyzing Industries and Competitors. New York: Simon and Schuster.

Rowley, J. Dunne, A., Lawlor, M., (2010). Young People's Use of Online Social Networking Sites. Journal of Research in Interactive Marketing, 4,1: 46-58.

Tahir, I., \& Abubakar, N. (2007). Service quality gap and customer satisfactions of commercial banks in Malaysia. Intl. Rev. Business Res. Papers, 3(4), 327-336.

Talik, E., Laguna, M., Wawrzenczyk-Kulik, M., Talik, W., Wiacek, G., Vingoe, G., Huyghe, P. (2012). The Astra Manager tool: A method of measuring competencies of micro firm's managers. Human Resource Management Research, 2: 9-14. 


\section{IMPACT ON COMPETITIVENESS OF VIETNAMESE}

Thompson, A.A., Strickland, A.J. \& Gamble J.E., (2007). Crafting and Executing Strategy: Concepts and Cases. $15^{\text {th }}$ Ed. New York, McGraw Hill.

Paper submitted

Paper accepted for publishing

Paper published online
28 October 2019

02 December 2019

05 February 2020 